\title{
Integral antioxidant activity of kefir for baby food from different manufacturers
}

\author{
(C) Yulia V. Shcherbakova ${ }^{*+}$ Farida Yu. Akhmadullina, \\ Kamila Sh. Kazimova, and Nasrulina K. Aydarovna \\ Department of Industrial Biotechnology. Kazan National Research Technological University. \\ K. Marks St., 72. Kazan, 420015. Republic of Tatarstan. Russia. \\ Phone:+7 (843)231-89-19.E-mail: balakirevajulia3@mail.ru
}

*Supervising author; ${ }^{+}$Corresponding author

Keywords: integral antioxidant activity, kefir for baby food, expiry date.

\begin{abstract}
In this paper, authors studied the integral antioxidant activity of kefir for baby food and the effect of the product's expiry date on this indicator. The integral antioxidant activity of kefir was determined on an "Expert-006" coulometer using coulometric titration with electro-generated bromine using rutin as a standard. The following points were chosen as control points for carrying out analytical work: release date, end of the expiry date, the period of time during which the food product, subject to storage conditions, must retain all of its properties specified in the regulatory documentation and a week after the expiration date. Such a trip allows us to determine a sample of fermented milk products that is distinguished by the highest biochemical value and high-quality preservation, and also to identify the brand of kefir for baby food and, as a result, the manufacturer, who should be preferred when buying goods. The object of the study in this work was several kefirs for children produced by OJSC «Zelenodolsk milk processing plant», OJSC «Lactis», LLC «Wimm Bill Dann». Studies have shown that the highest initial antioxidant activity was characterized by all control samples of kefir brand «For Babies» with the lowest declared expiry date. Moreover, an increase in the declared expiry date of sour-milk products led to a decrease in the value of the above indicator. A similar trend was observed when studying changes in the biochemical value of all studied samples during storage. The effect of storage duration on the integrated antioxidant activity of commercial products was evaluated by the level of its decrease (\%) at the time of determination relative to its initial value. It was revealed that the kefir produced by OJSC «Zelenodolsk milk processing plant" had the highest integral antioxidant activity and was subjected to the least changes in this indicator during storage among all children's kefirs studied in the work.
\end{abstract}

\section{References}

[1] S.V. Laptev, N.I. Mezentseva, E.P. Kamenskaya. Chemistry, microbiology, and examination of milk and dairy products. 2009. 237p. (russian)

[2] A. Tepel. Chemistry and physics of milk Per. from German, ed. Cand. Tech. Sciences. Filchakova S.A. St.-Petersburg: Profession. 2012. 832p. (russian)

[3] D.D. Adzhiev. Study of lipid peroxidation products, non-enzymatic and enzymatic antioxidant systems in the age dynamics of male rabbits. BSGB bulletin. 2010. Vol.14. No.4. P.674-684. (russian)

[4] I.K. Petrova. The study of the possibility of using electrohalogenated halogens in the pharmaceutical research of drugs of a number of bases and salts: abstract Candidate of Pharmaceutical Sciences: 04/14/02. I.K. Petrova. Samara. 2012.

[5] M.I. Retsky, S.V. Shabunin, G.N. Bliznetsova [et al.] Methodological position for studying the processes of free radical oxidation and the body's antioxidant defense system. FSEI HPE Voronezh State University. Voronezh. 2010. 70p. (russian)

[6] V.I. Ganina. Sour-milk symbiotic drink. Dairy industry. 2008. No.6. P.85. (russian)

[7] N.A. Glushanova. Biological properties of lactobacilli. State University for Advanced Medical Studies. Novokuznetsk. 2003. 50-58p. (russian)

[8] G.T. Rijkers, W.M. de Vos, R.J. Brummer. Health benefits and health claims of probiotics: Bridging science and marketing. British Journal of Nutrition. 2011. Vol.106. No.9. P.1291-1296.

[9] GOST 25179-2014 Milk and dairy products. Methods for determining the mass fraction of protein. Moscow: PHS Publishing House of Standards. 2015. 27p. (russian) 
[10] GOST R ISO 2446-2011 Milk. Method for determining fat content. Moscow: PHS Publishing House of Standards. 2012. 21p. (russian)

[11] GOST R 54760-2011 Compound dairy products and milk-based baby food. Determination of a highconcentration of mono- and disaccharides by high-performance liquid chromatography. Moscow: PHS Publishing House of Standards. 2012. 28p. (russian)

[12] Yu.V. Shcherbakova. Influence of heat treatment on the components of antioxidant milk system and its integral antioxidant activity. PhD Thesis for the degree of Cand. biologist of sciences (03.01.04). Scherbakova Yulia Vladimirovna; FSBEI HPE "Moscow State Academy of Veterinary Medicine and Biotechnology named after K.I. Scriabin". Moscow. 2011. 21p. (russian)

[13] Report on research work in the field of state support for research and development in the field of agriculture Min. Agriculture and Food RT. Subject: Development of a methodology for assessing the quality of dairy and dairy products based on integrated antioxidant activity. 2014. 46p. (russian)

[14] G.K. Budnikov, G.K. Ziyatdinova, V.I. Pogoreltsev. The use of the galvanostatic coulometry parameter in the clinical diagnosis of the antioxidant status of the human body. Kazan: KSMU. 2004. Vol.47. 34p. (russian)

[15] GOST R 51074-2003. Food Products. Information for the consumer. General requirements (as Amended by N 1). Moscow: PHS Publishing House of Standards. 2003. 26p. (russian) 